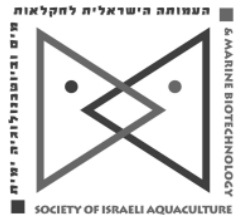

The IJA appears exclusively as a peerreviewed on-line Open Access journal at http://www.siamb.org.il Sale of IJA papers is strictly forbidden.

\title{
Comparison of Growth in Pike-Perch (Sander lucioperca) and Hybrids of Pike-Perch (S. lucioperca) $\times$ Volga Pike- Perch (S. volgensis)
}

\author{
T. Müller ${ }^{1} *$, M. Bódis ${ }^{2}$, B. Urbányi ${ }^{1}$, M. Bercsényi $^{2}$ \\ ${ }^{1}$ Department of Aquaculture, Institute of Environmental and Landscape \\ Management, Faculty of Agricultural and Environmental Sciences, Szent \\ István University, Gödöllö, H-2103 Páter Károly u.1, Hungary \\ ${ }^{2}$ Georgikon Faculty, Pannon University, Keszthely, H-8360 Deák F. u.16, \\ Hungary
}

(Received 1.2.10, Accepted 6.3.10)

Key words: Sander lucioperca, Sander volgensis, S. lucioperca x S. volgensis hybrids, comparative growth

\begin{abstract}
Growth of intensively cultured pike-perch Sander lucioperca (L.) and hybrids of pike-perch females $\times$ Volga pike-perch (S. volgensis Gmelin, 1789) males (1.75 g) were compared in a 35-day experiment. Fish were sorted into three groups (50 fish/aquarium): S. lucioperca grown separately (Group P), hybrids grown separately (Group $\mathrm{H}$ ), and a mixed group of $25 \mathrm{~S}$. lucioperca (Group Mp) grown together with 25 hybrids (Group Mh). The stocking density was $0.44 \mathrm{~g} / \mathrm{l}$. Final body weights were $6.83 \mathrm{~g}$, $6.54 \mathrm{~g}, 5.17 \mathrm{~g}$, and $4.84 \mathrm{~g}$, and specific growth rates were $3.9 \% /$ day, $3.75 \% /$ day, $3.1 \%$ /day, and $2.89 \%$ /day, for groups Mp, $\mathrm{P}, \mathrm{Mh}$, and $\mathrm{H}$, respectively. The weight, length, and specific growth rates of the $S$. lucioperca were significantly higher $(p<0.05)$ than those of the hybrids, whether grown separately or together. The feed conversion rate of the hybrids grown separately was significantly higher $(1.28 \mathrm{~g} / \mathrm{g})$ than all other groups. Further investigation is needed to study the growth performance of larger hybrids, to compare the hybrid with $S$. volgensis, and to investigate the possibility of cross hybridization.
\end{abstract}

* Corresponding author. Tel.: +36-28-522000/1659, fax: +36-28-410804, e-mail: Muller.Tamas@mkk.szie.hu 


\section{Introduction}

Inter-specific hybrids are produced to increase growth rate, combine desirable traits of two species, reduce unwanted reproduction by raising sterile or monosex stocks, take advantage of sexual dimorphism, increase harvestability, and increase environmental tolerance (Bartley et al., 2000). Species of the genus Sander have been hybred. Thanks to its better growth and lower sensitivity to environmental conditions (Siegwarth and Summerfelt, 1990 ), the hybrid saugeye (Sander vitreus $\times$ S. canadensis) is widely used in North American aquaculture and is stocked in natural waters for angling proposes (Tew et al., 2006) and as a predator to reduce recruitment and improve growth and size structure of overabundant crappie (Pomoxis spp.) populations (Galinat et al., 2002).

Pike-perch ( $S$. lucioperca) is one of the most valuable freshwater carnivorous fishes in Europe, not only as a food fish but also as a sport fish (Schulz, et al., 2007). Rearing pike-perch on formulated feed is one way to intensify its production (Molnár et al., 2004, 2007; Zakęś et al., 2006; Kestemont et al., 2007; Schulz et al., 2007). Volga pike-perch, S. volgensis (Gmelin, 1789), belongs to the same genus as S. lucioperca but its growth in nature is slower; it rarely exceeds $0.5 \mathrm{~kg}$, and it is less sensitive to environmental conditions. Sander volgensis can be found in water containing low levels of dissolved oxygen (Pintér, 2002). Early attempts to feed dry feed to $S$. volgensis suggest that its intensive rearing is possible (Bercsényi et al., 2001; Molnár et al., 2006).

The hybridization of S. lucioperca and S. volgensis in nature is rare (Müller et al., 2010), probably because of the differences in their reproductive ethology (Balon et al., 1977). The crossing of S. Iucioperca females $\times S$. volgensis males can be induced in the laboratory with common propagation practices; likewise, parental species can be bred in the laboratory (Müller et al., 2004). The aim of our work was to compare juvenile growth of $S$. lucioperca and a hybrid of the two species under laboratory conditions.

\section{Materials and Methods}

It is impossible to make a simultaneous three-way comparison between $S$. lucioperca, S. volgensis, and their hybrid because the reproduction and growth of S. lucioperca and S. volgensis significantly differ. Newly hatched larvae of S. lucioperca $(5.04 \pm 0.05 \mathrm{~mm}$, Ostaszewska, 2005) are larger than those of S. volgensis (3.25 $\pm 0.17 \mathrm{~mm}$, Müller et al., 2009) and the growth rate and final size of $S$. lucioperca in natural waters exceed those of $S$. volgensis. In Lake Balaton, Hungary, S. lucioperca grows to $145 \mathrm{~mm}$ during the first year (Bíró et al., 1998), while S. volgensis require more than two years to reach the same size (Specziár and Bíró, 2003). Therefore S. volgensis must be spawned one or two months earlier than S. lucioperca to obtain fingerlings of $3-4 \mathrm{~cm}$ that can be weaned from live food to formulated feed and to start a comparative experiment.

Fish. Larvae of S. lucioperca, originated from artificial propagation, were stocked in the fish farm of Makkos \& Társa Kft. in Fonyód, Hungary. Pondnursed juveniles were raised under natural conditions with zooplankton in 
monoculture, harvested at 3-4 cm, and transported to the Fish Laboratory of Pannon University, Georgikon Faculty of Agriculture, for acclimation to artificial conditions and weaning to dry feed.

Broodstock for hybridization originated from Aranyponty Zrt., a commercial fish farm in Sáregres-Rétimajor, Hungary (S. lucioperca), and from natural catches in Lake Balaton in Balatoni Halászati Zrt., Siófok, Hungary (S. volgensis). The parent stock was acclimatized for one month before breeding. Spawning of female S. Iucioperca was induced by gradually increasing the temperature in the tanks from $5^{\circ} \mathrm{C}$ to $14^{\circ} \mathrm{C}$ during 8 days and hormonal treatment with 250 IU human chorion gonadotropin (hCG) and 6 mg carp pituitary per fish on day 4 plus 500 IU hCG per fish on day 5 . Males of both Sander species were injected with a single dose of $4 \mathrm{mg}$ dry carp pituitary extract per $\mathrm{kg}$ body weight $24 \mathrm{~h}$ before milt stripping. Eggs of $\mathrm{S}$. lucioperca were fertilized by $S$. volgensis milt and incubated in a Zuger jar. Hybrid fry were grown exclusively on live food, first Paramecium and then Artemia and Chironomus larvae, for two months until they reached $3-4 \mathrm{~cm}$ body length.

At 3-4 cm, hybrid and S. lucioperca juveniles were weaned for two weeks onto Nutra 2.0, an extruded crumbled trout starter, with Chironomus larvae as a live food supplement. The weaned fish were reared in a recirculation unit.

When the juveniles reached an average body weight of $1.75 \mathrm{~g}$, three triplicate groups were formed. The first contained $S$. lucioperca juveniles (50 per aquarium), the second group contained hybrids (50 per aquarium), and the third contained $25 \mathrm{~S}$. Iucioperca juveniles plus 25 hybrids (per aquarium). In the third (mixed) group, hybrids were distinguished from S. lucioperca by their striped pattern and the size of their canine teeth (Specziár et al., 2009). At that time the hybrid juveniles were 101 days old and the S. Iucioperca juveniles were 78 days old.

The fish were stocked in 400-I aquaria with a recirculation system and flow rate of $4 \mathrm{l} / \mathrm{min}$. The aquaria were separated by an adjustable screen into two sections of 200 I for better feed acceptance, easier observation, and reduced daily maintenance (Fig. 1). Fish were stocked at 50 fish per aquarium (0.44 $\mathrm{g} / \mathrm{l}$ ). Light in the culture room fluctuated 10-50 lux. Except for the front, the walls of the aquaria were covered with gray plastic sheets to reduce light.

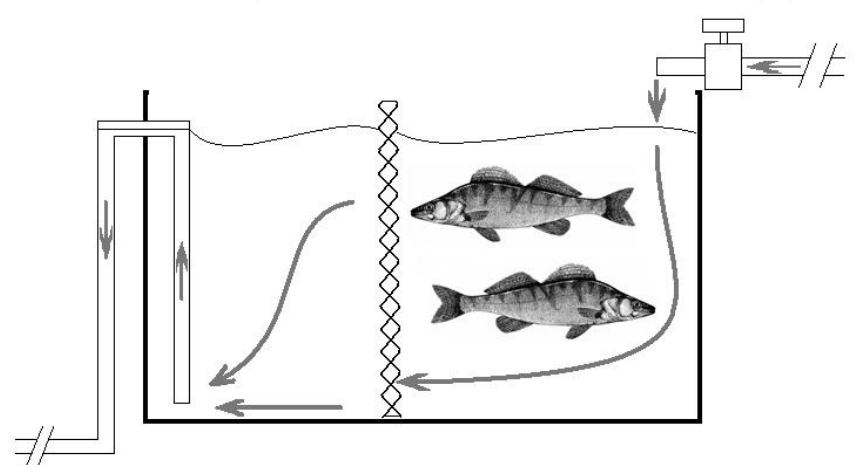

Fig. 1. Experimental aquarium with adjustable screen.

Feeding. The fish were fed Nutra 0 extruded crumbled trout starter for three weeks, followed by Classic Marine 1st $\mathrm{P}$ marine grower pellets for two weeks. Both feeds were manufactured by Hendrix Spa, Nutreco, Italy (Table 1 ). Feed was offered from automatic belt feeders for 12 h daily, 8:00-20:00. The 
Table 1. Proximate composition of compound feeds (according to manufacturer).

\begin{tabular}{lccc}
\hline & \multicolumn{3}{c}{ Feed } \\
\cline { 2 - 4 } & Nutra 2.0 & Nutra O O & $\begin{array}{c}\text { Classic } \\
\text { Marine }\end{array}$ \\
\hline Particle size (mm) & $0.7-1.1$ & $1.0-1.7$ & 1.7 \\
Crude protein (\%) & 54 & 54 & 50 \\
Crude fat (\%) & 18 & 18 & 12 \\
Crude ash (\%) & 10 & 10 & 10.5 \\
Crude fiber (\%) & 0.6 & 0.6 & 1.5 \\
Digestible energy (MJ/kg) & 19.4 & 19.4 & 16.5 \\
\hline
\end{tabular}

daily feeding rate was $3 \%$ of the body weight, revised weekly.

Water quality. Water temperature was maintained at 22.3土 $0.5^{\circ} \mathrm{C}$ and dissolved oxygen at $7.2 \pm 0.5 \mathrm{mg} / \mathrm{l}$. Both parameters were monitored daily. Mean values $\pm S D$ were $7.8 \pm 0.4 \mathrm{pH}$, $0.022 \pm 0.01 \mathrm{mg} / \mathrm{l}$ nitrite, $27.65 \pm$ $0.99 \mathrm{mg} / \mathrm{l}$ nitrate, $0.0425 \pm$ $0.0065 \mathrm{mg} / \mathrm{l}$ ammonium, and $1.58 \pm 0.2 \mathrm{mg} / \mathrm{l}$ phosphate, mea-sured on days 1,15 , and 35 .

Data collection and statistical analysis. Standard body length (to $1 \mathrm{~mm}$ ) and body weight (to $0.1 \mathrm{~g}$ ) of all fish in each group were recorded every week and the following parameters were calculated: condition factor $(\mathrm{K})$ as $100 \times$ $\mathrm{w}_{\mathrm{t}} /\left(\mathrm{I}_{\mathrm{t}}\right)^{3}$, where $\mathrm{w}_{\mathrm{t}}$ and $\mathrm{I}_{\mathrm{t}}$ are the body length and weight at time $\mathrm{t}$; specific growth rate $(S G R)$ as $100 \times\left(\ln w_{t}-\ln w_{0}\right) / t$, where $w_{0}$ is the initial weight and $t$ is the day of the observation; and feed conversion rate (FCR) as $F /\left(W_{t}-W_{0}\right)$ where $F$ is the total feed intake (dry weight). Statistical analyses were carried out with SPSS 7.5 for Windows (1996). One-way ANOVA with Tukey's test was used to compare growth rates, SGR, and FCR. Differences were considered significant when $p<0.05$.

\section{Results}

Growth rates significantly differed from the first week of the trial (Fig. 2). The final body weights of $S$. lucioperca ranged 4.2-11.6 g when raised separately and 4.3-10 g when raised together with hybrids; final weights of hybrids ranged 3-6.9 $\mathrm{g}$ when raised separately and 3.6-8 $\mathrm{g}$ when raised together with S. lucioperca. In both $S$. lucioperca and the hybrids, the average body weight was higher when they were raised together than when they were raised separately although the differences were not significant (Table 2). Growth performance was significantly lower in the hybrids than in the S. Iucioperca.

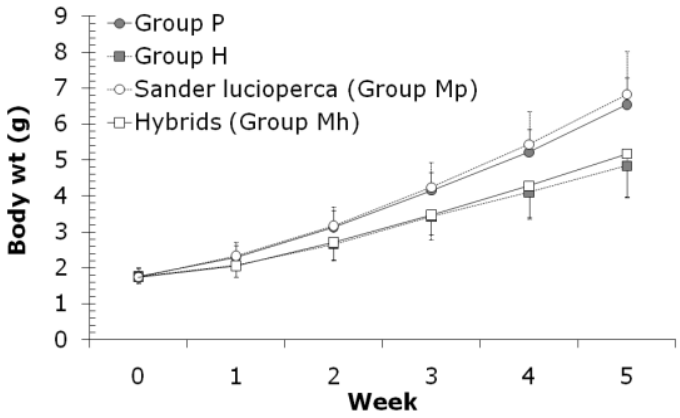

Fig. 2. Growth of Sander lucioperca (Group P) and hybrid $S$. lucioperca $\times S$. volgensis (Group $\mathrm{H}$ ) grown separately, and S. lucioperca (Group Mp) and hybrids (Group Mh) grown together.
There was no mortality during the experiment.

\section{Discussion}

The objective of the present study was to compare growth of the hybrid $S$. lucioperca $\times S$. volgensis with that of $S$. lucioperca. While $S$. lucioperca grows better than $S$. volgensis, it is one of the most sensitive fish species. The aim of the hybridization was to combine the favorable features of both species and see if the hybrid shows heterosis in some traits. 
Table 2. Growth of juvenile Sander lucioperca and hybrids of Sander lucioperca $\times$ S. volgensis (mean $\pm \mathrm{SD}$ ).

\begin{tabular}{lcccc}
\hline & \multicolumn{2}{c}{ Grown separately } & \multicolumn{2}{c}{ Grown together } \\
\cline { 2 - 5 } & $\begin{array}{c}\text { Sander } \\
\text { lucioperca } \\
\text { (Group P) }\end{array}$ & $\begin{array}{c}\text { Hybrids } \\
\text { (Group H) }\end{array}$ & $\begin{array}{c}\text { Sander } \\
\text { lucioperca } \\
\text { (Group Mp) }\end{array}$ & $\begin{array}{c}\text { Hybrids } \\
\text { (Group Mh) }\end{array}$ \\
\hline Initial body wt (g) & $1.76 \pm 0.23$ & $1.76 \pm 0.25$ & $1.74 \pm 0.17$ & $1.75 \pm 0.16$ \\
Final body wt (g) & $6.54 \pm 1.19^{\mathrm{a}}$ & $4.84 \pm 0.76^{\mathrm{b}}$ & $6.83 \pm 1.19^{\mathrm{a}}$ & $5.17 \pm 0.89^{\mathrm{b}}$ \\
Daily weight gain (g) & $0.14 \pm 0.003^{\mathrm{a}}$ & $0.09 \pm 0.003^{\mathrm{b}}$ & $0.15 \pm 0.09^{\mathrm{a}}$ & $0.1 \pm 0.01^{\mathrm{b}}$ \\
SGR & $3.75 \pm 0.07^{\mathrm{a}}$ & $2.89 \pm 0.07^{\mathrm{b}}$ & $3.9 \pm 0.13^{\mathrm{a}}$ & $3.1 \pm 0.13^{\mathrm{b}}$ \\
Initial length (cm) & $4.84 \pm 0.18$ & $4.83 \pm 0.18$ & $4.82 \pm 0.1$ & $4.83 \pm 0.13$ \\
Final length (cm) & $7.61 \pm 0.45^{\mathrm{a}}$ & $6.86 \pm 0.35^{\mathrm{b}}$ & $7.69 \pm 0.49^{\mathrm{a}}$ & $6.97 \pm 0.43^{\mathrm{b}}$ \\
Daily length gain (mm) & $0.79 \pm 0.02^{\mathrm{a}}$ & $0.58 \pm 0.02^{\mathrm{b}}$ & $0.82 \pm 0.03^{\mathrm{a}}$ & $0.61 \pm 0.03^{\mathrm{b}}$ \\
Initial condition factor & $1.54 \pm 0.11$ & $1.55 \pm 0.12$ & $1.55 \pm 0.12$ & $1.54 \pm 0.08$ \\
Final condition factor & $1.47 \pm 0.11^{\mathrm{a}}$ & $1.49 \pm 0.12^{\mathrm{ab}}$ & $1.49 \pm 0.09^{\mathrm{ab}}$ & $1.52 \pm 0.1^{\mathrm{b}}$ \\
FCR & $0.97 \pm 0.02^{\mathrm{a}}$ & $1.28 \pm 0.04^{\mathrm{b}}$ & $1.03 \pm 0.06^{\mathrm{a}}$ & $1.03 \pm 0.06^{\mathrm{a}}$ \\
\hline
\end{tabular}

Means with different superscripts significantly differ at $p<0.05$. There were no statistical differences in intra-group variability (ANOVA).

Sander lucioperca had significantly higher weight gains (361\% and $400 \%$, for the group grown separately and that grown together) than the hybrids ( $267 \%$ and $283 \%$, likewise) during the 5 -week experiment. The SGR values of the $S$. lucioperca and the FCR of $0.97 \mathrm{~g} / \mathrm{g}$ are similar to studies carried out with fish of a similar size (Hilge, 1990; Demska-Zakęś and Zakęś, 1997; Molnár et al., 2004).

When both kinds of juveniles were raised separately, they became accustomed to handling and the daily routine (siphoning, cleaning the walls) in a short time, but the hybrids poorly tolerated disturbance. The hybrids in the mixed group were not as stressed as the hybrids raised separately. On the other hand, it was much easier to train the hybrids to accept artificial food than the S. lucioperca. In our case, the survival rate of the hybrids was 90$95 \%$, compared to training losses in S. lucioperca of 31-88\% (Zakęś and Demska-Zakęś, 1996; Zakęś, 1997, 1999; Molnár et al., 2004) and survival of $100 \%$ in S. volgensis weaned to dry feed (Bercsényi et al., 2001). Thus, in intensive pike-perch production, the slower growth of the hybrids may be compensated by their more successful artificial food training.

Further investigations are needed to examine quantity traits of the hybrids, compare the hybrid with S. volgensis, and investigate the possibility of back-cross hybridization.

\section{Acknowledgements}

The authors would like to thank Mr. Ferenc Lévai and Mr. Péter Lévai (Aranyponty Zrt.) for providing the pike-perch broodstock, Mr. Ferenc Németh and Mr. István Szabó (Balatoni Halászati Zrt.) as well as Dr. András Specziár (MTA BLKI) for providing the Volga pike-perch breeders, and Makkos \& Társa $\mathrm{Kft}$. for providing the pike-perch fingerlings. We also thank Dr. Ákos Horváth, who reviewed and corrected the manuscript. This work was supported by the 
Bolyai János Fellowship of the Hungarian Academy of Sciences and Hungarian-Polish Bilateral project (PL-5/08).

\section{References}

Balon E.K., Momot W.T. and H.A. Regier, 1977. Reproductive guilds of percids: results of the paleogeographical history and ecological succession. $J$. Fish. Res. Bd. Canada, 34:1910-1921.

Bartley D.M., Rana K. and A.J. Immink, 2000. The use of inter-specific hybrids in aquaculture and fisheries. Rev. Fish Biol. Fish., 10:325-337.

Bercsényi M., Merth J., Födelmesi Z. and T. Müller, 2001, Rearing of pike-perch, perch and Volga pike-perch on pellet. p. 41. In: Abstracts, $25^{\text {th }}$ Sci. Conf. Fisheries and Aquaculture, Res. Inst. Fish. Aquacult. Irrigation, Szarvas, Hungary (in Hungarian).

Bíró P., Specziár A. and L. Tölg, 1998. A Balaton halállományának minőségi-mennyiségi felmérése (1995-98). pp. 134-137. In: J. Salánki, J. Padisák (eds.). A Balaton kutatásának 1997-es eredményei. VEAB and MEH BT, Veszprém (in Hungarian).

Demska-Zakęś K. and Z. Zakęś, 1997. Effect of 17 a-methyltestosterone on gonadal differentiation in pikeperch, Stizostedion lucioperca L. Aquacult. Res., 28:59-63.

Galinat G.F., Willis D.W., Blackwell B.G. and M.J. Hubers, 2002. Influence of a saugeye (Sauger $\times$ Walleye) introduction program on the black crappie population in Richmond Lake, South Dakota. N. Am. J. Fish. Manage., 22, 1416-1424.

Hilge V., 1990. Beobachtungen zur Aufzucht von Zandern (Stizostedion lucioperca) im Labor. Archiv für Fischereiwissenschaft, 40:167-173.

Kestemont P., Xu X.L., Hamza N., Maboudou J. and I.I. Toko, 2007. Effect of weaning age and diet on pike-perch larviculture. Aquaculture, 264:197-204.

Molnár T., Hancz C., Bódis M., Müller T., Bercsényi M. and P. Horn, 2004. The effect of initial stocking density on the growth and survival of the pike-perch fingerling reared under intensive conditions. Aquacult. Int., 12:181-189.

Molnár T., Müller T., Szabó G. and C. Hancz, 2006. Growth and feed conversion of intensively reared Volga perch (Stizostedion volgensis). Acta Agraria Kaposváriensis, 10:315-319.

Molnár T., Szabó A., Szabó G., Szabó C. and C. Hancz, 2007. Effect of different dietary fat content and fat type on the growth and body composition of intensively reared pike-perch Sander lucioperca (L.). Aquacult. Nutr., 12:173-182.

Müller T., Taller J., Nyitrai G., Kucska B., Cernák I. and M. Bercsényi, 2004. Hybrid of pike-perch (Sander lucioperca) and Volga perch (S. volgense GMELIN). Aquacult. Res. 35:915-916.

Müller T., Nyitrai G., Trenovszki M., Bercsényi M. and B. Urbányi, 2009. Artificial propagation of Volga pike-perch (Sander volgensis). pp. 436-437. In: EAS Spec. Publ. 38. Aquacult. Eur., Aug. 14-17, Trondheim, Norway. 
Müller T., Taller J., Kolics B., Kovács B., Urbányi B. and A. Specziár, 2010. First record of natural hybridization between pike-perch Sander lucioperca and Volga pike-perch S. volgensis. J. Appl. Icthyol., 26:481-484.

Ostaszewska T., 2005. Developmental stages of digestive system structures in pike-perch (Sander lucioperca). Electronic J. Ichthyol., 2:65-78.

Pintér K., 2002. Magyarország Halai (Fishes of Hungary). Akadémiai Kiadó, Budapest. pp. 186-187 (in Hungarian).

Schulz C., Bohm M., Wirth M. and B. Rennert, 2007. Effect of dietary protein on growth, feed conversion, body composition and survival of pike perch fingerlings (Sander lucioperca). Aquacult. Nutr., 13:373-380.

Siegwarth G.L. and R.C. Summerfelt, 1990. Growth comparison between fingerling walleye and walleye $\times$ sauger hybrids reared in intensive culture. Prog. Fish-Culturist, 52:100-104.

Specziár A. and P. Bíró, 2003. Population structure and feeding characteristics of Volga pike-perch, Sander volgensis (Pisces, Percidae), in Lake Balaton. Hydrobiologia, 506-509:503-510.

Specziár A., Bercsényi M. and T. Müller, 2009. Morphological characteristics of hybrid pike-perch (Sander lucioperca $q \times$ Sander volgensis đ) (Osteichthyes, Percidae). Acta Zoologica Academiae Scientiarum Hungaricae, 55:37-52.

Tew S.K., Conroy J.D. and D.A. Culver, 2006. Effects of lowered inorganic phosphorus fertilization rates on pond production of percid fingerlings. Aquaculture, 255:436-446.

Zakęś Z., 1997. Converting pond-reared pike-perch fingerlings, Stizostedion lucioperca (L.), to artificial food-effect of water temperature. Arch. Polish Fish., 5:313-324.

Zakęś Z., 1999. The effect of body size and water temperature on the results of intensive rearing of pike-perch, Stizostedion lucioperca (L.) fry under controlled conditions. Arch. Polish Fish., 7:187-199.

Zakęś Z. and K. Demska-Zakęś, 1996. Effects of diets on growth and reproductive development of juvenile pike-perch, Stizostedion lucioperca, reared under intensive culture conditions. Aquacult. Res., 27:841-845.

Zakęś Z., Kowalska A., Czerniak S. and K. Demska-Zakęś, 2006. Effect of feeding frequency on growth and size variation in juvenile pike-perch. Czech J. Anim. Sci., 51:85-91. 